\title{
Memories of Isadore Newman
}

\section{John Delane Williams}

Professor Emeritus, The University of North Dakota

Isadore Newman was the second editor of Multiple Linear Regression Viewpoints (MLRV), from 19731992. His term as editor saw several innovations. The first changes were a more pleasing format with a larger participation of the membership in authoring articles for the publication. A content change included monographs that were the complete content of issues of $M L R V$. The other aspect of this tribute is the relationship between the first two editors. This writer was the first editor of $M L R V$ and became professionally involved with Isadore and, through that process, they became involved in a long term friendship.

I sadore Newman was the editor of Multiple Linear Regression Viewpoints from 1973-1992; he was not the first editor of that journal; some background on its origin seems useful. . First, as part of the Presessions to the National meetings of the American Educational Research Association (AERA), in 1967, Joe Ward, Jr., Bob Bottenberg, Earl Jennings, and Deene Gott presented training for Multivariate Design and Analysis in Educational Research. For the next several years, they repeated this pre-session. At the 1970 meeting of AERA, I put forward a call to establish an interest group in Multiple Linear Regression. Earl Jennings was elected President and I was named editor of the Journal, which Earl and I agreed on naming it Multiple Linear Regression Viewpoints (MLRV). We also discussed approaches to doing multiple regression. I was the editor for the first three years. Early issues of the journal addressed setting up and accomplishing analysis of variance issues thru the use of multiple linear regression; Also setwise regression, multiple comparisons/contrasts, analysis of covariance (both one-way and two-way), and residual gains analysis were addressed thru multiple linear regression. Other issues. Including contrast coding and dummy coding ( 1 or 0 \} coding were addressed.

Isadore Newman was elected to be the editor in 1973.The University of Akron (Isadore's base) seemingly was less penurious than the University of North Dakota (my base). Having been relieved of the work involved in preparing each issue of the journal, I became a more frequent contributor under Isadore's editorship. One of the innovations Isadore started was the publication of monographs through $M L R V$. In fact I had three monographs published through $M L R V$, including Multiple Comparisons by Multiple Linear Regression (Williams, 1976); Path Analysis from a Regression Perspective (Williams, 1978); and Multiple Comparisons in Higher Dimensional Designs (Williams, 1980).

More importantly, a lifetime friendship began to bloom. We would generally meet at the AERA Annual meeting, in addition to our telephone conversations and written correspondence. We did meet in July 1979 at Disney World in Orlando. Like Keith McNeil's (2019) experience with Isadore in Alaska, the goings on in Disney World were mainly about regression and plans of doing projects together. One additional happening was the taking of a picture of his twins and my (then) two children, which remained on my desk at the University of North Dakota until my retirement in 2008. Isadore and I collaborated on several projects that became papers at conferences. Our first collaboration was on Repeated Measures designs, which was presented at the American Psychological Association meeting in Montreal in 1980 (Newman, Benz \& Williams, 1980).

Also in Montreal, Isadore's subtle humor showed itself. When we walked around the streets of Montreal, Isadore would approach people and ask, "Could I bother you for the time?" Without exception, the person would tell Isadore the time. This would happen every three to five minutes. Since I had a watch, and he never inquired about the time from me, Isadore explained, "I'm interested in what they might say." I eventually learned that when you asked Isadore a question, he would always answer-but was he really answering the question, or was he pulling your leg?

A second collaboration occurred at the AERA meeting in New York two years later regarding the Solomon four group designs (Williams \& Newman (1982). Another example of his subtle humor hit me. We were walking around the streets of New York as we walked by a man urinating on the sidewalk, without regard to passersby. Isadore said, "They have really cleaned up the city. It really used to be bad." I think he was pulling my leg. A third collaboration was on dependent binary data presented at the annual American Statistical Association meeting (Newman, Williams, \& Bobner, 1982). 
Yet another chapter of collaboration occurred in the 1987-88 school year. Isadore arranged for me an and my wife Jole to spend a year sabbatical in the Life Span Development and Gerontology program at the University of Akron, where I was also a Visiting Scientist. I also co-taught a course with Isadore on Multiple Regression and Multivariate Analysis. One of the courses I took was Psychology of Life time Development from Harvey Stern, who was the co-director the Life Span Development and Gerontology program with Isadore. In one class Dr. Stern stated that longitudinal research using repeated measures using age and cohort as the other dimensions necessarily had to be done separately as three two-way analyses. and a three analysis wasn't possible. I thought a little while, starting writing linear models and raised my hand, confidently announcing, "I can do it". His response was to say, well, then we'll put you on the program for the conference, Ohio Professional and Scientific Conference on Aging held in Toledo in several months. Isadore worked with me for the next several months getting a paper ready. This technique (Williams, 1991) provided the basis for my second dissertation (Williams \& Klug, 1996) on cognitive aspects of human aging; Isadore served as my outside statistical consultant for the degree. It is truly amazing what can be done with multiple linear regression!

One last situation where I was very thankful that Isadore was on the spot occurred a decade later at The Association for the Advancement of Educational Research in Jacksonville. I was presenting a paper on the qualitative-quantitative continuum as it related to the JFK Assassination. There were about 30 persons attending the session. As the session moved along, there seemed to be three positions held by the attendees; the vast majority took the position that only quantitative research had any scientific value. On the other side of the issue three persons took the position that only qualitative research was free of the inherent bias associated with quantitative research. Only Isadore and I saw the sense that qualitative research and quantitative research were on a continuum (Williams, 2001).

We planned to get together in January 2019 in Florida where Jole and I would visit Isadore and Carole prior to our taking a cruise out of Fort Lauderdale. Isadore's health took a significant turn for worse shortly before our planned get together. I am sorry that we weren't able to have this last meeting. Our meetings, whether in public or private were always interesting.

\section{References}

McNeil, K. (2019). Tribute to Isadore. General Linear Model Journal. 44(2),2-3.

Newman, I. Benz, C.R. \& Williams, J.D. (1980, September). Repeated Measures: Suggested approach for Simultaneous Independent and Dependent Measures. Presented at the American Psychological Association Annual Meeting, Montreal, QC.

Newman, I. Williams, J. D. \& Bobner, B., (1982, August). Dependent Binary Data: A Comparison of Regression \& Chi-Square Solutions. Presented at the American Statistical Association meeting. Cincinnati, $\mathrm{OH}$.

Williams, J. D. (1976). Multiple Comparisons by Multiple Linear Regression. (Monograph \#2) Multiple Linear Regression Viewpoints. 7(1).

Williams, J. D. (1978). Path Analysis from a Regression Perspective. Multiple Linear Regression Viewpoints. $9(2)$.

Williams, J. D. (1980). Multiple Comparisons in Higher Dimensional Designs. (Monograph \#5). Multiple Linear Regression Viewpoints. 10(3).

Williams, J. D. (1991). Age, Cohort and Period in Life-span Research: A Three-way Analysis with Logically Missing Cells. Multivariate Behavioral Research. 26, 631-654.

Williams, J. D. (2001).The qualitative-quantitative Continuum: Research on the JFK Assassination. In R. Hathaway (Ed.) The Annals of the Joint Meeting of the Association of the Advancement of Educational Research and the National Academy 1998-1999; pp. 317-328.

Williams, J. D. and Klug, M. (1996). Aging and Cognition- Methodological Differences in Outcome. Experimental Aging Research, 22, 219-224.

Williams, J.D and Newman, I. (1982, March). Using a Single Linear Model to Analyze a Solomon four Group Design. Presented at the American Educational Research Association. New York, NY.

Send correspondence to:

John D. Williams

University of North Dakota

Email: john.williams@ndsu.edu 